\title{
JOURNAL.RU
}

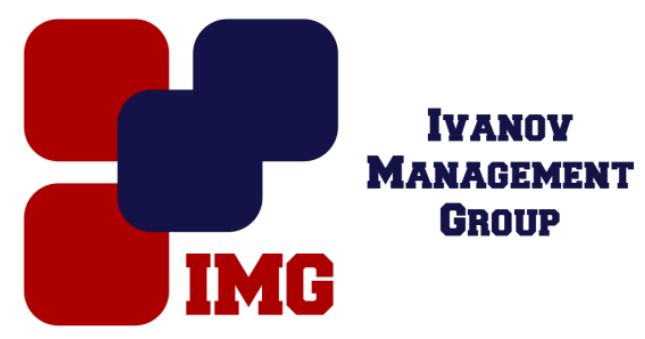

Лайпанова 3.М., Шидакова М.А. СевКавГГТА Черкесск, Россия

doi: $10.18411 / 1 \mathrm{j}-30-06-2017-22$

idsp 000001:1j-30-06-2017-22

\section{Порядок начисления заработной платы}

Оплата труда - система отношении, связанных с обеспечением установления и осуществления работодателем выплат работникам за их труд в соответствии с законами, иными нормативными правовыми актами, коллективным договором, соглашениями, локальными нормативными актами и трудовыми договорами.

Заработная плата- вознаграждение за труд в зависимости от квалификации работника, сложности, количества, качества и условии выполняемой работы, а также выплаты компенсационного и стимулирующего характера.

При поступлении любого работника на предприятие оформляется трудовой договор или заключается контракт. Одновременно издается приказ руководителя предприятия, второй экземпляр которого передается в бухгалтерию. На основании приказа заполняется личная карточка, открывается лицевой счет работника и делается запись в трудовой книжке.

Приказ является основанием для начисления работнику зарплаты с даты, указанной в нем и способ начисления ее (повременная или сдельная). Основным условием этих документов согласно статье 57 Трудового Кодекса РФ является размер заработной платы, своевременное начисление и правильный расчет которой должно обеспечить предприятие - работодатель.

Заработная плата начисляется, исходя из установленных на предприятии тарифов, сдельных расценок, окладов и сведений о фактически отработанном работниками времени или сведений об объемах выпущенной продукции. Расчет зарплаты производится на основании таких документов, как штатное расписание, положение об оплате труда, приказы о приеме на работу и трудовые договоры. 
Данными документами устанавливается размер и форма оплаты труда конкретного работника. Кроме того, существуют документы, на основании которых зарплата может быть изменена в большую или меньшую сторону: служебные записки, приказы о премировании и т.д. Положение об оплате труда предусматривает поощрительные выплаты и порядок начисления зарплаты применительно к каждой категории работников предприятия.

Существует несколько форм оплаты труда:

- повременная;

- сдельная.

При повременной оплате труда зарплата выплачивается в зависимости от отработанного времени и от квалификации работника.

При сдельной оплате труда зарплата зависит от количества произведенной продукции. Оплата труда не зависит от типа предприятия и производится в соответствии с Трудовым кодексом РФ. В государственных предприятиях систему оплаты труда устанавливает государство.

Сдельная заработная плата- это форма оплаты труда наемного работника, при которой заработок зависит от количества произведенных им единиц продукции или выполненного объема работ с учетом их качества, сложности и условии труда.

При сдельной заработной плате расчет производится исходя из сдельных расценок, установленных на изделие, и количества обработанных изделий. Учет выработки рабочих ведется бригадирами, мастерами или другими работниками, обязанных выполнять эти функции. Первичные документы для учета выработки продукции и начисления зарплаты разрабатываются самими предприятиями. Это могут быть наряды на сдельную работу, акты о приемке выполненных работ, маршрутные карты и т.д. Чаще всего сдельные расценки, установленные на изготовление единицы продукции, постоянны, поэтому заработок рабочего можно определить как произведение сдельной расценки на объем изготовленной продукции.

Повременная заработная плата- это форма оплаты труда наемного работника, при которой заработок зависит от количества фактически отработанного времени с учетом квалификации работника и условий труда.

При повременной форме оплаты труда зарплата зависит от количества отработанного времени. Для учета фактически отработанного времени ведется табель учета рабочего времени и табель расчета заработной платы.

Учет заработной платы на предприятии является одним из самых 
трудоемких, объемных и ответственных участков работы. Сложность бухгалтерского учета заработной платы заключается в том, что заработок считается для каждого сотрудника по отдельности с учетом применяемых в компании систем и форм оплаты труда. Большой штат сотрудников организации приводит к значительному объему расчетных операций.

Доля заработной платы в не денежной форме, не может превышать 20\% от общей суммы заработной платы. Если сотрудник в установленные сроки(3 дня с выдачи) не получил в кассе заработную плату, то производится её депонированиесдача в банк неполученной в срок заработной платы. При этом учет депонированных сумм ведется в специальных регистрах или книгах учета депонентов. Выплата депонированных сумм осуществляется на основании письменного заявления сотрудника в сроки выплаты очередной заработной платы.

Выплата заработной платы безналичным переводом осуществляется на основании письменного заявления сотрудника, с обязательным указанием банковских реквизитов. При этом запрещено выплачивать заработную плату в бонах, купонах, в форме долговых обязательств, расписок, в виде спиртных напитков и других предметов, в отношении которых установлены запреты или ограничения на их свободный оборот.

Основными государственными гарантиями оплаты труда работников являются:

- величина МРОТ;

- ограничение перечня оснований и размеров удержаний из заработной платы по распоряжению работодателя, а также размеров налогообложения доходов от заработной платы;

- ограничение оплаты труда в натуральной форме;

- обеспечение получения работником заработной платы в случае прекращения деятельности работодателя и его неплатежеспособности в соответствии с федеральными законами и др.

Система оплаты труда включает в себя:

- размеры должностных окладов;

- размеры тарифных ставок;

- размеры доплат и надбавок компенсационного характера, в т.ч. за работу в условиях, отклоняющихся от нормальных;

- системы доплат и надбавок стимулирующего характера и системы премирования. 
Положение об оплате труда утверждают своим приказом руководитель фирмы. Его согласовывают с профсоюзом (если таковой есть).

Различным категориям работников можно установить разные системы оплаты труда. Например, труд общепроизводственного и общехозяйственного персонала, как правило, оплачивают повременно (по окладам), а рабочих основного производства - сдельно. Сотрудники отделов сбыта обычно получают комиссионные от продаж.

Всю начисленную заработную плату можно подразделить на следующие виды:

- основная заработная плата;

- дополнительная заработная плата;

- премии по итогам работы за месяц.

Основная заработная плата начисляется в зависимости от принятых на предприятии форм оплаты труда, то есть повременной и повременнопремиальной.

Дополнительная заработная плата начисляется на основании документов, подтверждающих право на оплату за неотработанное время. К таким выплатам относятся:

- оплата основного или учебного отпуска;

- компенсация за неиспользованный отпуск;

- выплаты выходного пособия при увольнении;

- выплаты при направлении работника на курсы повышения квалификации;

- прочие выплаты согласно действующему законодательству.

Выплаты работнику дополнительной заработной платы производятся в сроки, определенные действующим законодательством.

Все перечисленные выплаты рассчитываются на основе среднего заработка. Во всех случаях средний заработок на день его выплаты не может быть менее установленного Федеральным законом минимального размера оплаты труда.

Премирование работников производится по итогам работы за месяц на основании «Положения об оплате труда». Конкретный размер премирования каждого работника определяется в зависимости от его вклада в общие результаты хозяйственной деятельности предприятия. Конкретные размеры премий отдельным работникам утверждаются приказом Генерального директора предприятия по результатам рассмотрения на Совете директоров, согласно 
докладных начальников отделов.

Выплачивается ежемесячная премия в размере до 200\% от тарифной ставки работника. Сумма премии конкретного работника может быть увеличена в пределах общей суммы средств на премирование за личный вклад в получение дополнительных доходов предприятия, проявленную инициативу и предприимчивость. 